\title{
BIOLOGIC THERAPY AND PREGNANCY - A TERTIARY CENTER EXPERIENCE
}

\author{
BIOLOŠKA TERAPIJA I TRUDNOĆA \\ - ISKUSTVO TERCIJARNOG CENTRA
}

\author{
Marija Bakula, Paula Kilić, Mislav Cerovec, Miroslav Mayer, Branimir Anić \\ Division of Clinical Immunology and Rheumatology, Department of Internal Medicine, \\ University of Zagreb School of Medicine, Universitiy Hospital Center Zagreb, Croatia \\ / Zavod za kliničku imunologiju i reumatologiju, Klinika za unutarnje bolesti, \\ Klinički bolnički centar Zagreb, Zagreb, Hrvatska
}

\author{
Corresponding author / Adresa autora za dopisivanje: \\ Marija Bakula, dr. med. \\ Division of Clinical Immunology and Rheumatology / Zavod za kliničku imunologiju i reumatologiju \\ Department of Internal Medicine / Klinika za unutarnje bolesti \\ University of Zagreb School of Medicine / Medicinski fakultet Sveučilišta u Zagrebu \\ Universitiy Hospital Center Zagreb / Klinički bolnički centar Zagreb
}

Kišpatićeva 12, Zagreb

Tel: 012388 330, Fax: 012388335

E-mail: marijaandrassy@gmail.com

Received/Primljeno: September 17, 2018 / 17. 9. 2018. Accepted/Prihvaćeno: February 10, 2019 / 10. 2. 2019.

\section{Abstract}

Treatment of inflammatory rheumatic diseases and control of disease activity have considerably improved after the introduction of biologic therapy over a decade ago. The safety profile of biologic therapy in the preconception period as well as during pregnancy and lactation is neccessary to consider when planning the treatment of young female patients.

Neither the Food and Drug Administration Agency nor the European Medicines Agency have declared biologic therapy safe during pregnancy. Both the European League Against Rheumatism and the British Society for Rheumatology proposed guidelines for the treatment of female rheumatology patients during pregnancy and lactation, and the American College of Rheumatology is currently developing guidelines for the therapeutic approach during pregnancy. On the other hand, there are numerous publications of pregnancy outcomes in patients treated with biologic therapy, with a small number of adverse effects.

We analyzed the modalities of biologic therapy and pregnancy outcomes in patients treated at our Department, during planned and unplanned pregnancies. Our results do not differ from the literature published to date. Among the patients described here, 15 were treated with an inhibitor of tumor necrosis factor- $\alpha$ and one with an IL- 6 inhibitor during or just before pregnancy. Only 2 patients stopped biologic therapy in compliance with the guidelines. Of the 16 aforementioned patients, 3 had to undergo medically-induced abortion; one patient because of a severe fetal malformation and the other two patients because they had been treated with conventional disease-modifying antirheumatic drugs, which are contraindicated during pregnancy.

KeYwORDs: Rheumatic diseases - drug therapy; Pregnancy complications - drug therapy; Antirheumatic agents - therapeutic use; Biological products - therapeutic use; Tumor necrosis factor-alpha - antagonists and inhibitors; Antibodies, monoclonal, humanized - therapeutic use; Pregnancy outcome

\section{SAŽETAK}

Biološka se terapija primjenjuje u liječenju upalnih reumatskih bolesti posljednjih desetak godina čime se znatno unaprijedila kontrola aktivnosti bolesti. Sigurnost primjene biološke terapije u pretkoncepcijskom razdoblju te tijekom trudnoće i laktacije veoma je važna pri planiranju liječenja mladih bolesnica.

Ni Američka agencija za hranu i lijekove ni Europska agencija za lijekove do danas nisu nijedan biološki lijek proglasile sigurnim u trudnoći. Europska liga protiv reumatizma i Britansko reumatološko društvo predložili su 
smjernice za liječenje reumatoloških bolesnica tijekom trudnoće i laktacije, dok Američko reumatološko društvo trenutačno izrađuje smjernice za terapijski pristup u trudnoći. S druge strane, objavljeni su mnogi radovi o ishodima trudnoća u bolesnica liječenih inhibitorima faktora tumorske nekroze i drugom biološkom terapijom, s malim brojem neželjenih ishoda.

Cilj je ovog rada bila analiza primjene biološke terapije u bolesnica koje su planirano ili neplanirano zanijele za vrijeme liječenja u našoj ustanovi te ishoda tih trudnoća. Naši se rezultati ne razlikuju od dosad objavljene literature. Petnaest prikazanih bolesnica primalo je jedan od blokatora tumorske nekroze- $\alpha$, a jedna bolesnica blokator interleukina-6 tijekom trudnoće ili neposredno prije začeća. Samo su dvije bolesnice poštovale preporučeni minimalni period od obustave terapije do začeća. Od navedenih 16 bolesnica 3 su imale medicinski indiciran prekid trudnoće: jedna zbog teške malformacije ploda, a dvije zbog terapije konvencionalnim lijekovima koji modificiraju bolest, a kontraindicirani su u trudnoći.

KLJUČNE RIJEČI: Reumatske bolesti - farmakoterapija; Komplikacije u trudnoći - farmakoterapija; Antireumatici - terapijska uporaba; Biološki lijekovi - terapijska uporaba; Čimbenik tumorske nekroze alfa - antagonisti i inhibitori; Humanizirana monoklonksa protutijela - terapijska uporaba; Ishod trudnoće

\section{INTRODUCTION}

During the last 20 years, advances in molecular biology, pharmacology, and understanding of the immune system have yielded novel therapies targeted against specific factors involved in the pathogenic mechanisms of autoimmune diseases. Biologic therapy has given a new perspective to a large number of patients and has significantly improved disease control. Physicians introduce biologic therapy after an inadequate effect of conventional synthetic disease-modifying antirheumatic drugs (csDMARDs).

The incidence of inflammatory rheumatic diseases is high in women of reproductive age. The safety profile of biologic therapy in the preconception period, as well as during pregnancy and lactation, is highly important and an ongoing concern during treatment planning for young female patients.

As yet, neither the Food and Drug Administration (FDA) nor the European Medicines Agency (EMA) have confirmed biologic therapy as safe during pregnancy. Tumor necrosis factor alpha inhibitors (TNFis), the interleukin (IL)-1 receptor antagonist (anakinra), and the IL-12 blocker (ustekinumab) have been labeled as risk category $\mathrm{B}$ by the FDA; animal reproduction studies have failed to demonstrate a risk to the fetus, but there are no controlled human studies. The IL-6 inhibitor (tocilizumab, TCZ), anti-CD20 monoclonal antibody (rituximab, RTX), lymphocyte T stimulation modulator (abatacept), as well as the B-cell activating factor inhibitor (belimumab) have been labeled as risk category C drugs; animal reproduction studies have shown adverse effects as well as increased rates of miscarriage and neonatal death after administration of higher doses.

Resarch and data on the safety profile of the aforementioned therapeutics in pregnant patients are too scarce to yield valid conclusions. Randomized clinical trials cannot be designed or carried out due to ethical issues. Therefore, observations are based on various

\section{UVOD}

Tijekom posljednjih dvadeset godina napretci $u$ molekularnoj biologiji, farmakologiji i razumijevanju imunosnog sustava pridonijeli su razvoju nove terapije usmjerene na čimbenike uključene $u$ patogenetski mehanizam autoimunosnih bolesti. Biološka terapija pružila je novu perspektivu mnogim bolesnicima i znatno unaprijedila kontrolu bolesti. Liječnici ju uvode nakon nezadovoljavajućeg učinka konvencionalnih lijekova koji modificiraju tijek bolesti (engl. Conventional synthetic disease-modifying antirheumatic drug csDMARD).

Incidencija upalnih reumatskih bolesti velika je $\mathrm{u}$ žena reproduktivne dobi. Zbog toga je sigurnost primjene biološke terapije u pretkoncepcijskom razdoblju te tijekom trudnoće i dojenja veoma važna i aktualno je pitanje pri planiranju liječenja mladih bolesnica.

Ni Američka agencija za hranu i lijekove (engl. Food and Drug Administration - FDA) ni Europska agencija za lijekove (engl. European Medicines Agency - EMA) još nisu proglasile nijedan biološki lijek sigurnim u trudnoći. FDA je klasificirala inhibitore faktora tumorske nekroze- $\alpha$ (TNFi), antagonist receptora interleukina (IL) 1 (anakinra) te blokator IL-12 (ustekinumab) u skupinu kategorije rizika „B“. To znači da testiranja na životinjama nisu dokazala njihovu štetnost u trudnoći, dok kontroliranih ispitivanja u ljudi nema. Inhibitor IL-6 (tocilizumab), monoklonsko protutijelo anti-CD20 (rituksimab), modulator stimulacije limfocita $\mathrm{T}$ (abatacept) te inhibitor faktora aktivacije limfocita B (belimumab) svrstani su u kategoriju „C“, što znači da su provedena ispitivanja na životinjskim modelima pokazala povećanu učestalost pobačaja i smrti novookoćene mladunčadi nakon izloženosti visokim dozama.

Podatci i istraživanja o sigurnosti primjene navedenih lijekova u trudnica nisu dovoljni da bi se mogao donijeti valjan zaključak. Randomizirani klinički pokusi ne mogu biti ustrojeni ni provedeni zbog etičkih razloga. Podatci se stoga dobivaju iz retrospektivnih 
retrospective studies which have been performed since the introduction of biologic therapy. So far, there has been a substantial amount of published research on pregnancy outcomes in patients treated with TNFi, with only a small number of adverse events (1-5).

The aim of our research was to analyze the application of biologic therapy in patients with planned or unplanned pregnancy treated at our Clinic and the outcomes of these pregnancies.

\section{PATIENTS AND METHODS}

This research was designed as a retrospective observational non-interventional study.

Data on female patients born after 1962 were extracted from the list of patients treated with biologic therapy from January 1, 2003 to September 30, 2017 (520 patients in total). After analyzing the patient records, we found a total of 18 female patients who were on biologic therapy just before or during pregnancy. The biologics had been introduced because of rheumatoid arthritis (RA; $n=9$ ), ankylosing spondylitis (AS, $\mathrm{n}=2)$, seronegative spondiloarthropathy $(\mathrm{SnSA}, \mathrm{n}=2)$, psoriatic arthritis (PsA, $n=2)$, juvenile idiopathic arthritis (JIA, $n=1)$, adult-onset Still's disease $(n=1)$, and Castleman disease $(\mathrm{n}=1)$.

The patients included in this study were treated with TNFis (infliximab (IFX), etanercept (ETA), adalimumab (ADA), golimumab (GOL)) and the IL-6 blocker TCZ. All patients were treated with generic biologic therapy and not with biosimilars.

According to the period of therapy cessation, the patients were divided into three groups (Table 1): 1. two patients discontinued biologic therapy 6 months before conceiving; 2 . five patients discontinued biologics just before conceiving; 3 . eleven patients were on biologic therapy during pregnancy.

It is worth noting that all information on patient compliance and regularity of medication taking as well as on the discontinuation of therapy (not just biologics, but also conventional therapy and glucocorticoids) was based on patient reports with the assumption that they were correct.

\section{RESULTS}

\section{Patients who discontinued biologic therapy according to treatment guidelines}

Two patients stopped taking biologic therapy 6 months before conceiving. Both of them were treated with GOL for AS.

A patient born in 1987 had been treated for HLAB27 positive AS with radiologic signs of sacroileitis since age 13. She was on csDMARDs (sulphasalzine (SSZ), chloroqine) along with glucocorticoids (GC) and nonsteroidal anti-inflammatory drugs (NSAIDs) ispitivanja koja se provode od uvođenja bioloških lijekova u kliničku praksu. Objavljeni su mnogi radovi o ishodima trudnoća u bolesnica liječenih TNFi-jem, s malim brojem štetnih događaja $(1-5)$.

Cilj je ovog rada bio utvrditi udio i opisati bolesnice koje su planirano ili neplanirano zanijele za vrijeme liječenja biološkom terapijom u našoj ustanovi te ishode tih trudnoća.

\section{BOLESNICE I METODE}

Ovo je ispitivanje ustrojeno kao retrospektivno, opservacijsko, neintervencijsko ispitivanje.

Iz popisa bolesnika koji su primali biološku terapiju u razdoblju od 1. siječnja 2003. godine do 30 . rujna 2017. godine (ukupno 520 bolesnika) prikupljeni su podatci o bolesnicama rođenima 1962. godine i poslije. Uvidom u povijesti bolesti izdvojeno je 18 bolesnica koje su primale biološku terapiju neposredno prije ili tijekom trudnoće radi liječenja reumatoidnog artritisa (RA, $\mathrm{n}=9$ ), ankilozantnog spondilitisa (AS, $\mathrm{n}=2$ ), seronegativne spondiloartropatije $(\mathrm{SnSA}, \mathrm{n}=2)$, psorijatičnog artritisa (PsA, $n=2)$, juvenilnog idiopatskog artritisa (JIA, $n=1$ ), Stillove bolesti u odrasloj dobi $(\mathrm{n}=1)$ i Castlemanove bolesti $(\mathrm{n}=1)$.

Bolesnice uključene $\mathrm{u}$ ispitivanje liječene su TNFi-jevima (infliksimab (IFX), etanercept (ETA), adalimumab (ADA), golimumab (GOL)) i blokatorom IL-6 (TCZ). Sve su bolesnice liječene izvornim lijekovima, a ne njihovim biološki sličnim inačicama.

S obzirom na vrijeme prekida biološke terapije, bolesnice su podijeljene u tri skupine (tablica 1.). Prvu skupinu činile su dvije bolesnice koje su zbog planiranja trudnoće biološku terapiju prekinule 6 mjeseci prije začeća prema smjernicama za biološke lijekove. U drugoj skupini bilo je pet bolesnica koje su terapiju prekinule neposredno prije začeća, dok je u trećoj skupini bilo jedanaest bolesnica koje su primale biološku terapiju u vrijeme začeća i tijekom trudnoće.

Informacije o redovitom uzimanju lijekova prema uputama, kao i o prestanku njihova uzimanja (bioloških lijekova, konvencionalne terapije i glukokortikosteroida) prikupljene su iz iskaza bolesnica s pretpostavkom da su točne.

\section{REZULTATI}

\section{Bolesnice koje su prekinule biološku terapiju prije začeća prema smjernicama za liječenje}

Dvije bolesnice prekinule su terapiju biološkim lijekom 6 mjeseci prije začeća, obje boluju od AS-a i obje su primale Simponi (GOL).

Prva bolesnica, rođena 1987. godine, boluje od AS-a pozitivnog na HLA-B27 s radiološkim znakovima sakroileitisa od 13. godine. Tijekom 11 godina bila je na terapiji DMARD-ima (sulfasalazinom (SSZ) i klo- 
TABLE 1. Patients treated with biologic therapy before and/or during pregnancy

TABLICA 1. Bolesnice liječene biološkom terapijom prije i/ili u vrijeme trudnoće

\begin{tabular}{|c|c|c|c|c|c|c|c|c|c|}
\hline $\begin{array}{l}\text { No. } \\
\text { R.br. }\end{array}$ & $\begin{array}{l}\text { Year of } \\
\text { birth } \\
\text { Godina } \\
\text { rodenja }\end{array}$ & $\begin{array}{l}\text { Diagnosis } \\
\text { Dijagnoza }\end{array}$ & $\begin{array}{l}\text { Year of } \\
\text { pregnancy } \\
\text { Godina } \\
\text { trudnoće }\end{array}$ & $\begin{array}{l}\text { Age during } \\
\text { pregnancy } \\
\text { Dob u } \\
\text { vrijeme } \\
\text { trudnoće }\end{array}$ & $\begin{array}{l}\text { Biologic } \\
\text { therapy } \\
\text { Biološka } \\
\text { terapija }\end{array}$ & $\begin{array}{l}\text { Start of } \\
\text { biologic } \\
\text { therapy } \\
\text { Početak } \\
\text { biološke } \\
\text { terapije }\end{array}$ & $\begin{array}{l}\text { Disease activity } \\
\text { Aktivnost bolesti }\end{array}$ & $\begin{array}{l}\text { Pregnancy } \\
\text { number } \\
\text { R.br. } \\
\text { trudnoće }\end{array}$ & $\begin{array}{l}\text { Pregnancy outcomes and comments } \\
\text { Ishodi trudnoće i napomene }\end{array}$ \\
\hline \multicolumn{10}{|c|}{ 1) Planned therapy cessation 6 months before pregnancy / Planirani prekid biološke terapije 6 mjeseci prije trudnoće } \\
\hline 1 & 1987. & AS & 2017. & 30 & $\begin{array}{l}\text { Simponi } \\
\text { (GOL) }\end{array}$ & 2014. & BASDAI 1,6 & 1 & $\begin{array}{l}\text { Healthy child born full term } \\
\text { Zdravo dijete u terminu }\end{array}$ \\
\hline 2 & 1977. & AS & 2013. & 36 & $\begin{array}{l}\text { Simponi } \\
\text { (GOL) }\end{array}$ & 2011. & BASDAI 4,6 & 1 & $\begin{array}{c}\text { No data } \\
\text { Nema podataka }\end{array}$ \\
\hline \multicolumn{10}{|c|}{ 2) Last administration of biologic therapy shortly (less than a month) before pregnancy / Posljednja doza biološkog lijeka primjenjena neposredno pred začeće } \\
\hline 3 & 1981. & RA & 2010. & 26 & $\begin{array}{l}\text { Remicade } \\
\quad \text { (IFX) }\end{array}$ & 2003. & I & 1 & $\begin{array}{l}\text { Twins born full term, one died of sepsis } \\
\text { at } 2 \text { weeks, the other healthy } \\
\text { Blizanci u terminu, jedan u 2. tj života } \\
\text { preminuo zbog sepse, } 2 \text {. blizanac zdrav }\end{array}$ \\
\hline 4 & 1972. & RA & 2013. & 41 & $\begin{array}{l}\text { Enbrel } \\
\text { (ETA) }\end{array}$ & 2009. & DAS28-SE 3,65 & 2 & $\begin{array}{l}\text { Healthy child born full term } \\
\text { Zdravo dijete u terminu }\end{array}$ \\
\hline 5 & 1979. & RA & 2010 & 31 & $\begin{array}{l}\text { Enbrel } \\
\text { (ETA) }\end{array}$ & 2006. & DAS28-SE 1,64 & 1 & $\begin{array}{l}\text { Healthy child born full term } \\
\text { Zdravo dijete u terminu }\end{array}$ \\
\hline 6 & 1972. & RA & 2012. & 40 & $\begin{array}{l}\text { Enbrel } \\
\text { (ETA) }\end{array}$ & 2011. & I & 1 & $\begin{array}{l}\text { Healthy child born full term } \\
\text { Zdravo dijete u terminu }\end{array}$ \\
\hline 7 & 1989. & PsA, SpA & 2017. & 32 & $\begin{array}{l}\text { Simponi } \\
\text { (GOL) }\end{array}$ & 2015. & BASDAI 4,4 & 1 & $\begin{array}{l}\text { Healthy child born full term } \\
\text { Zdravo dijete u terminu }\end{array}$ \\
\hline 8 & 1974. & RA & 2012. & 38 & $\begin{array}{l}\text { Remicade } \\
\quad \text { (IFX) }\end{array}$ & 2012. & DAS28-SE 2,84 & 1 & $\begin{array}{l}\text { Healthy child born full term } \\
\text { Zdravo dijete u terminu }\end{array}$ \\
\hline \multicolumn{10}{|c|}{ 3) Biologic therapy given during pregnancy / Biološka terapija tijekom trudnoće } \\
\hline 9 & 1995. & PsA & 2014. & 19 & $\begin{array}{l}\text { Remicade } \\
\text { (IFX) }\end{array}$ & 2010. & I & 1 & $\begin{array}{l}\text { Medically-induced abortion (at } 10 \mathrm{w} . \text { ) } \\
\text { Medicinski opravdan pobačaj u } 10 . \mathrm{tj}\end{array}$ \\
\hline 10 & 1993. & JIA & 2008. & 16 & $\begin{array}{l}\text { Enbrel } \\
\text { (ETA) }\end{array}$ & 2007. & l & 1 & $\begin{array}{l}\text { Healthy child born full term } \\
\text { Zdravo dijete u terminu }\end{array}$ \\
\hline 12 & 1989. & $\begin{array}{c}\text { Still } \\
\text { adultorum }\end{array}$ & 2015. & 27 & $\begin{array}{l}\text { RoActemra } \\
\text { (TCZ) }\end{array}$ & 2011. & DAS28-SE 0,5 & 1 & $\begin{array}{l}\text { Healthy child born full term } \\
\text { Zdravo dijete u terminu }\end{array}$ \\
\hline 13 & 1986. & RA & 2017. & 31 & $\begin{array}{l}\text { Enbrel } \\
\text { (ETA) }\end{array}$ & 2016. & BASDAI 3.1 & 1 & $\begin{array}{l}\text { Healthy child born full term } \\
\text { Zdravo dijete u terminu }\end{array}$ \\
\hline 14 & 1980. & RA & 2016. & 36 & $\begin{array}{l}\text { Remicade } \\
\text { (IFX) }\end{array}$ & 2014. & DAS28-SE 2,13 & 1 & $\begin{array}{l}\text { Healthy child born full term } \\
\text { Zdravo dijete u terminu }\end{array}$ \\
\hline 15 & 1995. & $\begin{array}{l}\text { RA, HLA } \\
\text { B27+ }\end{array}$ & 2016. & 22 & $\begin{array}{l}\text { Enbrel } \\
\text { (ETA) }\end{array}$ & 2015. & $\begin{array}{c}\text { BASDAI } 1,1 \\
\text { DAS28-SE } 1,13\end{array}$ & 1 & $\begin{array}{l}\text { Healthy child born full term } \\
\text { Zdravo dijete u terminu }\end{array}$ \\
\hline 16 & 1987. & $\mathrm{RA}, \mathrm{SpA}$ & $\begin{array}{l}\text { 1. } 2015 \text {. } \\
\text { 2. } 2017 \text {. }\end{array}$ & $\begin{array}{l}1.28 \\
2.30\end{array}$ & $\begin{array}{l}\text { 1. Remicade } \\
\text { (IFX) } \\
\text { 2. Enbrel } \\
\text { (ETA) }\end{array}$ & 2014 . & $\begin{array}{l}\text { 1. DAS28-SE } 4,46 \\
\text { 2. DAS28-SE } 3,2\end{array}$ & $\begin{array}{l}1 \\
2\end{array}$ & $\begin{array}{l}\text { 1. Abortion (spina bifida) } \\
\text { 1. Pobačaj (spina bifida) } \\
\text { 2. Healthy child born full term } \\
\text { 2. Zdravo dijete u terminu }\end{array}$ \\
\hline 17 & 1983. & RA & 2016. & 33 & $\begin{array}{l}\text { RoActemra } \\
\quad(\text { TCZ) }\end{array}$ & 2014. & DAS28-SE 1,53 & 1 & $\begin{array}{l}\text { Spontaneous abortion (at } 7 \mathrm{w} \text {.) } \\
\text { Spontani pobačaj } \mathrm{u} 7 . \mathrm{tj}\end{array}$ \\
\hline 18 & 1988. & PsA & 2014. & 26 & $\begin{array}{l}\text { Humira } \\
\text { (ADA) }\end{array}$ & 2009. & DAPSA 22,4 & 1 & $\begin{array}{l}\text { Medically-induced abortion (at } 7 \text { w.) } \\
\text { Medicinski opravdan pobačaj u } 7 . \text { tj }\end{array}$ \\
\hline
\end{tabular}

for 11 years. Treatment with GOL started after clinical impairment with a BASDAI score of 7.9, and as the disease soon went into persistent remission (BASDAI 0.9 in 12/2011), there was no need for analgesic therapy. The patient started planning pregnancy in 2016 and therefore was advised to discontinue biologic therapy. rokinom), uz glukokortikoide (GK) i nesteroidne antireumatike (NSAR). Zbog pogoršanja kliničke slike (BASDAI 7,9) započeto je liječenje Simponijem uz znatno poboljšanje nakon druge primjene lijeka (u prosincu 2011., BASDAI 0,9) te perzistentnu remisiju, bez potrebe za analgeticima. Bolesnica je 2016. počela 
Six months later, she conceived. The AS reactivated during pregnancy, with a maximum BASDAI score of 6.2. The pregnancy proceeded without complications, delivery was on term, and the baby was healthy and had a normal neonatal development.

A patient born in 1977 was diagnosed with AS when she was 27. GOL was introduced due to persistent active disease. After a year on biologic therapy, the AS went into remission and the patient started planning pregnancy. She conceived 6 months after discontinuing biologic therapy, in $4 / 2013$. The last follow-up at our Clinic was in $1 / 2014$, in the $39^{\text {th }}$ gestational week. The patient was scheduled for a cesarean section because of the underlying disease. Afterwards, we lost contact with the patient and there is no available medical data, neither on the course of the delivery nor on the further disease development.

\section{Patients who discontinued biologic therapy just before pregnancy}

There were five patients who stopped taking biologic therapy just before conception.

A patient born in 1981 had had seropositive RA since she was 10 . Treatment with IFX started 10 years after the disease was diagnosed and the patient had been on biologic therapy during the following 7 years, along with methotrexate (MTX) and GC permanently. In 4/2010 the last dose of IFX was administered and right afterwards the patient conceived twins. During pregnancy she was on GC $6 \mathrm{mg}$ daily along with paracetamol and folic acid, but the RA mildly exacerbated. The pregnancy went without complications and delivery was on term in $1 / 2011$. Unfortunately, one child died of sepsis 2 weeks after. The other twin was helathy, with no signs of infection or other complications.

A patient born in 1972 had had persistent active RA since she was 34 . After 3 years of therapy with leflunomide (LEF) and GC, ETA was introduced and csDMARD continued. Several months later the disease was well controlled with a DAS 28-ESR score of 4.41 and remained stable during the next 3 years. An unplanned pregnancy was discovered in $1 / 2014$, in the same month the patient received the last dose of ETA. Since the patient had not been taking LEF for a longer period of time, a termination of pregnancy was not considered. The patient delivered a healthy baby on term. ETA was reintroduced one year later, after the patient stopped breastfeeding.

A patient born in 1979 had been treated for RA since age 23. In the first year of the disease she was treated with MTX and GC, but ADA was soon introduced. Despite the therapy, disease activity remained high. Therefore, three years later the patient was started on ETA, and better disease control was achieved. In 2010 the therapy with ETA and MTX was discontinued be- planirati trudnoću te joj je savjetovano da prekine terapiju. Zanijela je šest mjeseci nakon prekida primjene Simponija. Tijekom trudnoće bolest se počela pogoršavati, s maksimalnim rezultatom BASDAI-ja od 6,2. Sama trudnoća protekla je bez komplikacija i bolesnica je u terminu rodila zdravo dijete koje se normalno razvijalo u novorođenačkom razdoblju.

Druga bolesnica, rođena 1977. g., boluje od AS-a od 27. godine. Zbog perzistirajuće aktivne bolesti bolesnica je započela terapiju Simponijem. Nakon godinu dana biološke terapije i zadovoljavajuće remisije bolesti prekinuta je primjena Simponija zbog planiranja trudnoće. Bolesnica je zanijela 6 mjeseci nakon prekida terapije, u travnju 2013. godine. Na posljednjoj kontroli, u siječnju 2014., bolesnica je bila u 39. tjednu uredne trudnoće, koja se planirala dovršiti carskim rezom zbog osnovne bolesti. Poslije se bolesnica nije javljala na kontrolu niti postoji nama dostupna medicinska dokumentacija o porođaju i daljnjem tijeku bolesti.

\section{Bolesnice koje su posljednju dozu biološke terapije primile neposredno prije začeća}

U ovoj je skupini pet bolesnica u kojih je biološka terapija prekinuta neposredno prije začeća.

Treća bolesnica, rođena 1981. godine, boluje od seropozitivnog RA od 10. godine. Primjena Remicadea (IFX) započela je 10 godina nakon postavljene dijagnoze te ga je bolesnica uzimala tijekom idućih 7 godina, uz metotreksat (MTX) i GK trajno. U travnju 2010. primijenjena je posljednja doza biološkog lijeka, nakon čega je bolesnica neposredno zanijela blizance. Tijekom trudnoće uzimala je GK u dozi od $6 \mathrm{mg}$ na dan uz paracetamol i folnu kiselinu; pratila se blaga egzacerbacija bolesti. Trudnoća je protekla uredno i dovršena je u terminu, u siječnju 2011. Jedno je novorođenče preminulo 2 tjedna nakon rođenja zbog sepse, a drugo je dijete zdravo, bez težih infekcija i drugih komplikacija u razvoju.

Četvrta bolesnica, rođena 1972., boluje od perzistirajućeg aktivnog RA od 34. godine. Nakon 3 godine terapije leflunomidom (LEF) i GK-om uvedena je i primjena Enbrela (ETA). Nekoliko mjeseci poslije bolest je bila u zadovoljavajućoj kontroli (DAS 28-SE 4,41), uz postupno poboljšanje tijekom iduće 3 godine. $U$ siječnju 2014. bolesnica je neplanirano zanijela, mjesec dana nakon posljednje doze Enbrela. Budući da bolesnica već dulje vrijeme nije uzimala LEF, prekid trudnoće nije bio razmatran. Bolesnica je rodila zdravog dječaka u terminu. Terapija Enbrelom nastavljena je godinu dana poslije, nakon prestanka dojenja.

Peta bolesnica, rođena 1979., započela je liječenje RA u 23. godini. Prvih godinu dana primala je MTX i GK kojima je zatim pridodana Humira (ADA), no bez većeg učinka na aktivnost bolesti. Tri godine poslije u 
cause the patient started planning pregnancy. Nevertheless, a minimum safety period from therapy cessation to pregnancy had not been reached because the patient conceived within a month. The pregnancy proceeded without complications and disease activity remained low with GC $10 \mathrm{mg}$ daily. Delivery was on term and the baby was healthy. In 4/2011, because of RA relapse, ETA was reintroduced.

A patient born in 1972 was diagnosed with high-activity RA when she was 27 and soon ETA was introduced. According to the medical records, she stopped taking biologic therapy just before conceiving, in $3 / 2012$. The pregnancy was without complications. During the whole pregnancy the patient was on GC 10 $\mathrm{mg}$ daily and the RA was in remission. She underwent cesarean section in term and a healthy child was born. Postpartum recovery and neonatal development were without complications.

A patient born in 1989 was diagnosed with SnSA when she was 25. A year later, GOL was introduced and the disease went into stable remission. Two years after, biologic therapy was discontinued because of planned in-vitro fertilization. Two months later (in 1/2017) the patient conceived. The pregnancy was without complications and the patient delivered by cesarean section in the $35^{\text {th }}$ gestational week. The child was healthy (Apgar 10/10) and further neonatal development was normal.

\section{Patients who were on biologic therapy at the time of conception and during pregnancy}

The last patient group comprised 11 patients who were on biologic therapy during pregnancy, with two of them also taking csDMARDs (MTX and LEF).

A patient born in 1974, with a history of addiction, had been treated for RA since she was 23. During 2009 she was on methadone and concomitant therapy with ribavirin and pegilated interferon due to hepatitis $C$, which soon went into remission. For a long period of time she was on csDMARDs, first SSZ and then MTX, and GC permanently. The patient received the first dose of IFX 15 years after RA was established. It was later discovered that she had been taking only $5 \mathrm{mg}$ of MTX weekly instead of the prescribed $15 \mathrm{mg}$ weekly. The biologic therapy induced substantial clinical improvement (DAS28-ESR score 2.84) and the patient was on IFX every 8 weeks, following a standard protocol. At every biologic therapy application, a thorough clinical examination was conducted and every time the patient reported regular menstrual cycles. In 2/2013, before the $9^{\text {th }}$ aplication of IFX, the attending physician suspected pregnancy. The patient was promptly referred to a gynecologist who confirmed a pregnancy of 31 weeks. Fetal ultrasound did not reveal any malformations. The biologic therapy, as well as MTX, was in- terapiju je uveden Enbrel kojim je postignuta bolja kontrola bolesti. Terapija Enbrelom i MT-om prekinuta je 2010. zbog planiranja trudnoće, no nije ispunjen uvjet sigurnog razdoblja stanke od terapije: bolesnica je zanijela isti mjesec. Trudnoća je protekla bez komplikacija, s niskom aktivnosti bolesti uz terapiju GK-om u dozi od $10 \mathrm{mg}$ na dan. Bolesnica je rodila zdravo dijete u terminu. U travnju 2011. nastavljena je terapija Enbrelom zbog relapsa RA.

Šesta bolesnica, rođena 1972., boluje od RA visoke aktivnosti od 27. godine, zbog čega je uvedena terapija Enbrelom. U medicinskoj dokumentaciji zabilježeno je da je prekinula biološku terapiju neposredno prije začeća, u ožujku 2012. Trudnoća je protekla uredno. Tijekom cijele trudnoće bolesnica je uzimala terapiju GK u dozi od $10 \mathrm{mg}$ na dan i bolest je bila u remisiji. Carskim rezom rodila je zdravo dijete u terminu. Poslijeporođajni tijek i razvoj djeteta bili su uredni.

Sedmoj bolesnici, rođenoj 1989., postavljena je dijagnoza SnSA u 25. godini, a godinu dana poslije započeto je liječenje Simponijem. Uz terapiju je bolest bila u stabilnoj remisiji. Dvije godine poslije liječenje Simponijem obustavljeno je radi planiranog postupka potpomognute oplodnje te je bolesnica nakon dva mjeseca, u siječnju 2017., zanijela. Trudnoća je protekla bez komplikacija i carskim je rezom u 35. tjednu rođeno zdravo dijete (Apgarina indeksa 10/10) koje je uredno napredovalo.

\section{Bolesnice koje su uzimale biološku terapiju u vrijeme začeća i tijekom trudnoće}

U posljednju skupinu spada jedanaest bolesnica koje su primale biološku terapiju u vrijeme začeća i tijekom trudnoće, a dvije od njih uzimale su i DMARD (MTX i LEF).

Osma bolesnica, s anamnezom ovisnosti, rođena 1974. g., liječi se zbog RA od 23. godine. Tijekom 2009. liječena je metadonom te ribavirinom i pegiliranim interferonom zbog hepatitisa $\mathrm{C}$ koji je otad u remisiji. Niz godina bolesnica je liječena primjenom DMARD-a, prvo SSZ-a, a zatim MTX-a uz GK trajno. Bolesnica je primila prvu dozu Remicadea 15 godina nakon postavljene dijagnoze RA. Naknadno se saznaje da je bolesnica, umjesto propisanih $15 \mathrm{mg}$ na tjedan, uzimala MTX u dozi od $5 \mathrm{mg}$ na tjedan. Uz biološku terapiju došlo je do jasnoga kliničkog poboljšanja (DAS 28-SE 2,84 ) te je Remicade primjenjivan prema standardnom protokolu svakih 8 tjedana. Tijekom cijelog perioda liječenja bolesnica je navodila da ima redovite menstrualne cikluse. Pri kliničkom pregledu u veljači 2013., prije 9. primjene lijeka, pregledom trbuha postavljena je sumnja na trudnoću. Hitnim ginekološkim pregledom u Klinici za ženske bolesti i porode potvrđena je trudnoća u 31. tjednu. Ultrazvučni pregled nije otkrio nikakve malformacije ploda. Odmah su prekinute bio- 
stantly discontinued and the patient was on GC throughout the rest of the pregnancy. The patient delivered in $4 / 2013$, at home, in the $36^{\text {th }}$ gestational week. The newborn was healthy and with no complications in the further neonatal development. After ablactation in 5/2013, IFX was reintroduced, along with MTX and GC. Nevertheless, the patient was soon lost to follow-up.

A patient born in 1995 was diagnosed with PsA when she was 15 . Shortly after PsA was established, she was started on IFX in another (pediatric) institution. She had been receiving biologic therapy for 4 years without pause. Throughout that time she had also been on LEF. At the first visit to our Clinic, within transition to adult rheumatology, pregnancy was suspected and confirmed by ultrasound. Application of IFX and LEF was instantly discontinued. Even though it was an unplanned pregnancy at a very early stage (less than 10 weeks) which started while the patient was on therapy with LEF, termination of pregnancy was medically indicated. In 6/2014 biologic therapy with IFX was continued.

A patient born in 1993 was diagnosed with JIA when she was 3 . Medical records from a pediatric rheumatology clinic showed that she had been on MTX until 2008 and that the last dose of ETA was administered in $7 / 2009$. The same month the patient delivered a healthy baby, after a normal pregnancy, without complications. Since 2009 she has been in follow-up at our Clinic and in 2/2010 ETA was reintroduced.

A patient born in 1988 had been in hematologic follow-up for multicentric Castleman disease. The disease was well controlled with low doses of GC. According to the medical documentation, high titres of anticardiolipin IgM antibodies were permanently present in patient's serum and, despite prophylactic therapy with low-molecular-weight heparin, she had three habitual abortions in the first trimester of pregnancy $\left(2^{\text {nd }}\right.$ and $3^{\text {rd }}$ weeks). In 1/2017, a consultation at our Clinic was held to consider treatment options in a potential pregnancy. TCZ was introduced as induction therapy during the IVF procedure and then discontinued in the first trimester of pregnancy. The patient was 21 weeks pregnant when this paper was finished and by that time no complications in the fetal development had been described.

A patient born in 1989 was diagnosed with adult Still's disease when she was 21 . She was treated with TCZ during the following 4 years. The last dose was administered in 9/2015, when the patient was 4 weeks pregnant. The pregnancy proceeded without complications and the patient delivered a healthy baby in 6/2016. Further postpartal recovery as well as neonatal development was normal.

A patient born in 1986 was diagnosed with SnSA when she was 29. After 9 months of therapy with ADA, loška terapija i terapija MTX-om, a liječenje je nastavljeno samo primjenom GK i analgeticima. Početkom travnja 2013. g. bolesnica je u 36. tjednu trudnoće kod kuće rodila zdravo dijete koje se normalno razvijalo, bez komplikacija. U bolesnice je u svibnju 2013., nakon ablaktacije, nastavljena primjena Remicadea, MTX-a i GK, no nedugo zatim izgubljena je iz praćenja.

Deveta bolesnica, rođena 1995., boluje od PsA od 15. godine. Odmah nakon postavljene dijagnoze započeta je terapija Remicadeom u drugoj (pedijatrijskoj) ustanovi. Terapiju je primala četiri godine bez stanke. Uz to je redovito uzimala i LEF. Pri prvom pregledu u našoj Klinici, u sklopu tranzicijske ambulante i potrebe prelaska na adultnu reumatologiju, postavljena je sumnja na trudnoću koja je i potvrđena ultrazvučnim pregledom. Primjena Remicadea i LEF-a odmah je prekinuta. Budući da je bila riječ o ranoj i neplaniranoj trudnoći (manje od 10 tjedana) te da je do začeća došlo uz terapiju LEF-om, medicinski je bio indiciran prekid trudnoće. U lipnju 2014. nastavljena je primjena Remicadea.

Deseta bolesnica, rođena 1993., započela je liječenje JIA u 3. godini. Iz povijesti bolesti pedijatrijske reumatološke klinike vidljivo je da je MTX prestala uzimati 2008., a posljednja doza Enbrela primijenjena je u srpnju 2009. Isti je mjesec bolesnica rodila zdravo dijete, a trudnoća je protekla uredno. Od 2009. kontrolira se $\mathrm{u}$ našoj Klinici. Enbrel je ponovo uveden u terapiju u veljači 2010.

Jedanaesta bolesnica, rođena 1988., pod redovitom je kontrolom hematologa zbog multicentričnog oblika Castlemanove bolesti. Bolest je bila dobro kontrolirana niskim dozama GK. U medicinskoj dokumentaciji bilježe se trajno pozitivna antikardiolipinska protutijela razreda IgM u visokom titru te habitualni pobačaji (tri zaredom) u prvom tromjesečju trudnoće (2. i 3. tjedan) usprkos profilaktičkoj terapiji niskomolekularnim heparinom. U siječnju 2017. zatražen je konzilijarni pregled reumatologa zbog pitanja terapije u trudnoći. Uvedena je RoActemra (TCZ) kao indukcijska terapija za pripremu trudnoće i predviđenog postupka potpomognute oplodnje. Primjena TCZ-a prekinuta je u prvom tromjesečju. U vrijeme pisanja ovog rada bolesnica je bila u 21. tjednu trudnoće, koja je dotad protjecala bez komplikacija u razvoju ploda.

Dvanaesta bolesnica, rođena 1989. g., boluje od Stillove bolesti od 21. godine. Liječena je RoActemrom tijekom četiri godine. Posljednja primjena lijeka bila je u rujnu 2015., kada je terapija obustavljena zbog otkrivene trudnoće od četiri tjedna. U lipnju 2016., nakon uredna tijeka trudnoće, u terminu je rođeno zdravo dijete, a poslijeporođajni tijek bio je bez komplikacija i u djeteta i u majke.

Trinaesta bolesnica, rođena 1986. g., boluje od SnSA od 29. godine. Nakon 9 mjeseci terapije Humirom pri- 
a pregnancy of 4 weeks was discovered and biologic therapy discontinued. The patient delivered a healthy baby on term and there were no complications in the further neonatal development. Since there were no signs of disease activity, biologic therapy was not reintroduced.

A patient born in 1980 was diagnosed with RA and treated with IFX. Because of disease remission a year after the introduction of biologic therapy, MTX was stopped. During a regular follow-up in $1 / 2016$, a pregnancy of 4 weeks was discovered and IFX discontinued. A healthy baby was born in term, after a normal pregnancy without complications. There was no need for reintroducing biologic therapy, since the RA remained in remission.

A patient born in 1995 was diagnosed with RA and was HLA-B27 positive. She was treated with ETA. The last dose of biologic therapy was administered in the $8^{\text {th }}$ week of gestation, in $12 / 2016$. The patient delivered a helathy baby in term ( $39^{\text {th }}$ week) after a short hospitalization due to premature rupture of membranes. The labor was induced but there were no postpartum complications.

A patient born in 1987 started receiving IFX 10 years after she was diagnosed with RA. The last dose of biologic therapy was administered in 4/2015 and the same month the patient conceived. Unfortunately, in the $28^{\text {th }}$ week of gestation an abortion had to be induced, because of spina bifida and severe brain malformation in the fetus. A month later, IFX was reintroduced. Due to high disease activity, after 3 months the patient was switched to GOL, and 6 months later she was switched to ETA. The patient conceived again in 2/2017 and therapy with ETA was continued until the end of the $1^{\text {st }}$ trimester. In 10/2017 the patient delivered a healthy baby by cesarean section.

A patient born in 1983 was diagnosed with RA and treated with IFX. After the $5^{\text {th }}$ application of therapy, in $6 / 2016$, treatment was temporarily stopped because of a Bartholin gland inflammation. At follow-up at the gynecologist 2 weeks later, a pregnancy of 6 weeks was discovered. Unfortunately, the patient had a spontaneous miscarriage the next week. She then conceived in 4/2017 and delivered a healthy baby by cesarean section in term.

A patient born in 1988 was diagnosed with PsA. Seven years later, biologic therapy was introduced. The patient was started on ADA. Because of persistent infections, a switch to IFX had been attempted, but soon discontinued due to primary inefficiency. ETA was then introduced, but the patient soon developed cutaneous side-effects. In 2014 ADA was reintroduced and three months later a pregnancy was discovered. Since the patient had been on MTX permanently during the prior 2 years, an abortion was medically advised. Since $1 / 2015$ the patient has been treated with ustekinumab. mjena tog lijeka obustavljena je zbog novootkrivene trudnoće od četiri tjedna. Trudnoća je protekla uredno i bolesnica je rodila zdravo dijete u terminu. U bolesnice nije došlo do aktivacije bolesti nakon trudnoće pa biološka terapija nije nastavljena.

Četrnaesta bolesnica, rođena 1980. g., boluje od RA i liječena je Remicadeom. Zbog dobre kontrole bolesti prekinut je MTX godinu dana nakon uvođenja biološke terapije. Pri redovitoj kontroli u siječnju 2016. utvrđena je trudnoća u trajanju od četiri tjedna, zbog čega je obustavljena primjena Remicadea. Trudnoća je protekla bez komplikacija i bolesnica je rodila zdravo dijete u terminu. Nakon porođaja biološka terapija nije nastavljena.

Petnaesta bolesnica, rođena 1995. g., liječila se Enbrelom zbog RA uz pozitivan HLA-B27. Primjena lijeka prekinuta je u 8. tjednu trudnoće, u prosincu 2016. U 39. tjednu trudnoće bolesnica je hospitalizirana zbog otjecanja plodne vode, induciran je porođaj te je rođeno zdravo dijete. Poslijeporođajni tijek i u majke i djeteta bio je uredan.

Šesnaesta bolesnica, rođena 1987. g., počela je primati Remicade 10 godina nakon postavljene dijagnoze RA. Posljednju dozu biološkog lijeka primila je u travnju 2015. i isti je mjesec zanijela. U 28. tjednu trudnoće učinjen je medicinski indiciran prekid trudnoće zbog spine bifide i teške nerazvijenosti mozga ploda. Mjesec dana poslije nastavljena je terapija Remicadeom. Nakon tri mjeseca, zbog visokoaktivne bolesti, bolesnica je prebačena na Simponi, a zatim je 6 mjeseci poslije, ponovo zbog neučinkovitosti, u bolesnice terapija promijenjena u Enbrel. Bolesnica je ponovo zanijela $u$ veljači 2017., a terapija Enbrelom nastavljena je do kraja prvog tromjesečja. U listopadu 2017. bolesnica je rodila zdravog dječaka carskim rezom.

Sedamnaesta bolesnica, rođena 1983. g., liječena je Remicadeom zbog RA. Nakon pete primjene lijeka, $\mathrm{u}$ lipnju 2016., lijek je privremeno obustavljen zbog upale Bartholinove žlijezde. Na kontrolnome ginekološkom pregledu 2 tjedna poslije utvrđena je trudnoća $\mathrm{u}$ trajanju od šest tjedana, no već je u sedmom tjednu trudnoća završila spontanim pobačajem. Bolesnica je ponovo zanijela u travnju 2017., a carskim je rezom u terminu rodila zdravo dijete.

Osamnaesta bolesnica, rođena 1988. g., boluje od PsA. Sedam godina nakon dijagnoze započeta je primjena biološke terapije. Prvotno je terapijski uvedena Humira, a zbog stalno prisutnih infekcija pokušao se uvesti Remicade koji se pokazao primarno nedjelotvoran. Zatim je uveden Enbrel, ali bolesnica je ubrzo dobila kožne nuspojave. Terapija Humirom ponovo je uvedena 2014., a tri mjeseca poslije ustanovljena je trudnoća. Budući da je bolesnica tijekom prethodne dvije godine trajno uzimala MTX, savjetovan je medicinski opravdan prekid trudnoće. Od siječnja 2015. bolesnica prima ustekinumab. 


\section{DISCUSSION}

There are numerous publications describing the effects of biologic therapy and csDMARDs on the course and outcomes of pregnancy. To date, the FDA and EMA have not declared biologic agents safe during pregnancy or lactation (6-11). The pharmaceutical industry recommends avoiding biologic therapy during this period. Nevertheless, there are many reports and literature reviews with results showing no greater incidence of adverse effects of such a therapy in pregnant patients. (1-5, 12-17) Systematic literature reviews highlight the effects of other factors on pregnancy outcomes, such as disease activity and patients' comorbidities, which have not yet been thoroughly reviewed. $(18,19)$ Given that among biologic agents today TNFis have been in the longest use for the treatment of autoimmune diseases, the experience with TNFi application in pregnancy is also the greatest. Most of the reports on TNFi therapy during pregnancy have not associated the treatment with adverse effects. Some publications raise questions about the association of this therapy with higher incidences of congenital malformations such as the VACTERL syndrome (vertebral defects, anal atresia, cardiac defects, tracheoesophageal fistula, renal anomalies, limb abnormalities), (20, 21) but the aforementioned analyses are doubious due to methodological errors. $(21,22)$

The patients described here have been treated with TNFis (ETA, IFX, GOL, ADA) and the IL-6 blocker (TCZ) during or just before pregnancy.

TNFis exist as monoclonal antibodies (IFX, ADA, GOL, certolizumab-pegol (CZP)) or as fusion proteins (ETA). Monoclonal antibodies consist of human immunogloblin G1 Fc fragments (except for CZP) and Fab fragments, which bind to the TNF- $\alpha$ molecule. Depending on the type of Fab fragment, monoclonal antibodies used today can be chimeric (e.g., IFX, RTX), humanized (e.g., TCZ), or human (e.g., GOL, ADA). It is well-known that only the IgG antibody significantly crosses the human placenta. During the first two trimesters, fetal concentrations of IgG molecules are low in the umbilical cord, while their transfer through the placenta rapidly increases in the third trimester of pregnancy. (23) The IgG1 subclass of immunoglobulins is transferred most efficiently across the placenta. (24) Although according to the FDA all TNFis belong to the risk category $\mathrm{B}$, the minimum recommended time for treatment cessation before pregnancy differs from one TNFi to the other. Therefore, for GOL and IFX the recommended period is 6 months, for ADA 5 months, and for ETA 3 weeks. (7-11) Nevertheless, according to the recommendations of the European League Against Rheumatism (EULAR), treatment with IFX, ADA, and GOL should be discontinued around the $20^{\text {th }}$ gestational week, while therapy with

\section{RASPRAVA}

U mnogim su radovima opisani učinci biološke terapije, kao i terapije temeljnim antireumaticima na tijek i ishod trudnoće. FDA i EMA nisu proglasile nijedan biološki lijek sigurnim u vrijeme trudnoće i laktacije $(6$ - 11). Proizvođači bioloških lijekova preporučuju izbjegavanje takve terapije u tom razdoblju. Ipak, mnogi izvještaji i pregledi literature ne pronalaze veću incidenciju neželjenih događaja u trudnoći u bolesnica na biološkoj terapiji $(1-5,12-16)$. U sistematskim pregledima literature napominje se da ishod trudnoće ovisi i o drugim faktorima, pogotovo o aktivnosti osnovne bolesti i komorbiditetima trudnice, te da njihov utjecaj na tijek trudnoće često nije dovoljno razmotren $(17,18)$. Među danas dostupnom biološkom terapijom TNFi se najdulje primjenjuje u liječenju autoimunosnih bolesti pa stoga i postoji najviše iskustva $\mathrm{u}$ njegovoj primjeni tijekom trudnoće. Neki radovi upozoravaju na moguću povezanost ove terapije $s$ većom incidencijom kongenitalnih malformacija kao što je sindrom VACTERL (engl. vertebral defects, anal atresia, cardiac defects, tracheo-esophageal fistula, renal anomalies, and limb abnormalities) $(19,20)$, no navedena su istraživanja dovedena u pitanje zbog metodoloških pogrešaka $(20,21)$.

Prikazane su bolesnice tijekom trudnoće ili neposredno prije začeća liječene primjenom TNFi-ja (ETA, IFX, GOL, ADA) te blokatorom IL-6 (TCZ).

Lijekovi koji blokiraju TNF- $\alpha$ proizvode se kao monoklonska protutijela (infliksimab, golimumab, adalimumab, certolizumab-pegol (CZP)) ili kao fuzijski proteini (etanercept). Monoklonska protutijela sastoje se od Fc-regije (izuzev CZP-a) ljudskog imunoglobulina G1 (IgG1) te Fab-dijela koji veže molekulu TNF- $\alpha$. Ovisno o načinu proizvodnje Fab-dijela, monoklonska protutijela koja se danas rabe u reumatologiji mogu biti kimerična (npr., infliksimab, rituksimab), humanizirana (kao blokator IL-6 (TCZ)) ili humana (npr., golimumab, adalimumab). Poznato je da jedino protutijelo IgG prolazi kroz uteroplacentalnu barijeru. U prva dva tromjesečja trudnoće fetalne su koncentracije molekula IgG u pupkovini niske, dok se u trećem tromjesečju njihov transport kroz placentu naglo povećava (22). Upravo je podskupina imunoglobulina IgG1 ta koja se najbolje transportira kroz posteljicu (23). Iako je čitava skupina TNFi-ja svrstana u kategoriju rizika „B“ prema FDA, minimalno preporučeno razdoblje od prestanka uzimanja lijeka do začeća razlikuje se za pojedine lijekove. Tako je to razdoblje za golimumab i infliksimab 6 mjeseci, za etanercept 3 tjedna, a za adalimumab 5 mjeseci $(7-11)$. Prema preporukama Europske lige protiv reumatizma (EULAR), pak, terapiju IFX-om, ADA-om i GOL-om valja obustaviti oko 20. tjedna gestacije, dok se primjena ETA može nastaviti do 32. tjedna (18). Ovdje je potrebno izdvojiti CZP, po- 
ETA can be continued up to the $32^{\text {nd }}$ week of gestation. (19) The last approved TNFi, CZP, used for the treatment of RA (2009), AS, and PsA (2013), has to be singled out. This humanized monoclonal antibody differs from other TNFis in its pegilated Fab fragment and absence of the Fc region. Pegilation enhances the solubility of CZP, prolongs its half-life, and reduces its immunogenicity. Furthermore, because it lacks an Fg-region, this monoclonal antibody cannot bind to the neonatal $\mathrm{Fc}$ receptor $(\mathrm{FcRn})$ and consequently does not actively cross the placenta. $(25,26)$ In a recently published paper on pregnancy outcomes in $625 \mathrm{pa}$ tients treated with CZP (every patient receiving CZP during the first trmester and one third of the patients receiving CZP during the whole pregnancy), no increase in the incidence of adverse events has been reported, compared to the healthy population. (27) There are studies comparing the concentration of each TNFi (IFX, ADA, ETA, and CZP) in the umbilical cord and neonatal peripheral blood of neonates whose mothers had been exposed to biologic therapy during pregnancy. $(28,29,30)$ Concentrations of IFX and ADA were significantly higher in the umbilical cord than in the mother's serum (IFX by $160 \%$ and ADA by $153 \%$ ). At the same time, concentration of CZP in the umbilical cord was slightly higher than in the mother's serum (by 3.9\%). Moreover, IFX and ADA were traceable in the neonatal blood up to 6 months after cessation of the mother's treatment, while the concentrations of CZP were undetectable. (29) According to the EULAR 2016 recommendations, CZP application is possible during the whole pregnancy due to its molecule size and low bioavailability, as well as to a decreased utero-placental transfer. Treatment is also compatible with breastfeeding. (19)

ETA is a genetically engineered fusion protein which consists of two identical TNF- $\alpha$ soluble receptor molecules (TNFR2) bound to an IgG1 Fc fragment. $(8,31)$ In most of the reports published to date there was no association of ETA treatment with adverse prgnancy outcomes. Nevertheless, some reports question the effect of ETA on the occurrence of fetal malformations (such as the aforementioned VACTERL). (32, 33) There is no strict instruction for a safe interval between the last application and conception. In the official product information it is advised to stop treatment with ETA at least 3 weeks before conceiving, since it crosses the placenta and is secreted into breast milk. It is also advised not to vaccinate babies within 16 weeks after their mother had the last drug application. (8) Still, according to the last EULAR recommendations for the therapy of pregnant patients, ETA can be safely administered until the $30^{\text {th }}$ to $32^{\text {nd }}$ gestational week and even during the whole pregnancy if the disease activity is high. It is safe during breastfeeding due to its low sljednji odobreni lijek iz skupine TNFi-ja koji se primjenjuje za liječenje RA od 2009., a za liječenje AS-a i PsA od 2013. Ovo humanizirano monoklonsko protutijelo razlikuje se od ostalih TNFi-ja prema pegiliranom Fab-odsječku, dok mu Fc-regija nedostaje. Pegilacija poboljšava topljivost lijeka i produljuje mu poluživot te smanjuje njegovu imunogeničnost. Nadalje, zbog nedostatka Fc-regije ovo monoklonsko protutijelo ne može se vezati za neonatalni Fc-receptor $(\mathrm{FcRn})$ te ne prolazi aktivno kroz posteljicu tijekom trudnoće $(24,25)$. Nedavno objavljeni rad o ishodima 625 trudnoća žena koje su bile liječene primjenom CZP-a (u svih majka u prvom tromjesečju, a u trećine njih tijekom cijele trudnoće) ne opisuje povećanu učestalost neželjenih događaja u usporedbi sa zdravom populacijom (26). Objavljena su ispitivanja koja su uspoređivala koncentraciju pojedinih TNFi-ja (IFX, ADA, ETA i CZP) u pupkovini i perifernoj krvi novorođenčadi majka koje su bile izložene biološkoj terapiji tijekom trudnoće $(27$ - 29). Dok su koncentracije IFX-a i ADA bile znatno više u pupkovini nego u majčinoj krvi (IFX $160 \%$ i ADA 153\%), koncentracija CZP-a u pupkovini bila je tek za 3,9\% viša od one u majčinoj krvi. Nadalje, IFX i ADA bili su mjerljivi u krvi novorođenčadi do 6 mjeseci nakon prestanka terapije u majke, dok su koncentracije CZP-a bile nemjerljive (28). Prema preporukama EULAR-a iz 2016., primjena CZP-a moguća je tijekom cijele trudnoće zbog veličine molekule i niske bioraspoloživosti te smanjenog prijenosa kroz uteroplacentalnu barijeru, a primjena lijeka kompatibilna je i s dojenjem (18).

ETA je fuzijski protein stvoren genetičkim inženjeringom koji se sastoji od dvije identične molekule topljivog receptora za TNF- $\alpha$ (TNFR2), vezane za Fc regiju humanog IgG1. Odobren je za liječenje RA, PsA, poliartikularnoga juvenilnog idiopatskog artritisa, AS-a i plak-psorijaze $(8,30)$. U većini objavljenih radova nije nađena poveznica primjene ETA-e s neželjenim ishodima trudnoće, iako postoje neki izvještaji o malformacijama (već spomenuti sindrom VACTERL) gdje se utjecaj navedenog lijeka dovodi u pitanje (31, 32). Ne postoji točna odrednica za sigurnosni interval od posljednje primjene do začeća. U službenom opisu lijeka savjetuje se prestanak terapije najmanje tri tjedna prije začeća te se upozorava na izlučivanje lijeka kroz posteljicu i u majčino mlijeko. Savjetuje se ne cijepiti dojenčad u 16 tjedana od posljednje primjene lijeka u majke (8). Ipak, prema posljednjim smjernicama EULAR-a za primjenu lijekova u trudnih bolesnica, ETA se može sa sigurnošću primjenjivati do 30. ili 32. tjedna trudnoće, pa čak i tijekom cijele trudnoće ako je riječ o aktivnoj bolesti. Siguran je pri dojenju zbog niske bioraspoloživosti i veličine molekule (18). Ni u jedne od prikazanih bolesnica koje su bile liječene ETA-om neposredno prije začeća i za vrijeme trudno- 
bioavailability and size. (19) None of the patients described here and treated with ETA before or during pregnancy, presented with adverse pregnancy outcomes or impairment in the neonatal development.

IFX is a chimeric human-mouse monoclonal antibody of the IgG1 subclass, engineered by recombinant DNA technology. It has the same affinity for both the soluble and transmembrane forms of TNF. According to the official drug instruction, treatment with IFX during pregnancy and breastfeeding is not advised, and a minimum period of 6 months without therapy is recommended. (9) Some reports mention a minimum period of 2 months, due to its half-life. Regarding adverse pregnancy outcomes, there is no statistically significant distinction between patients on IFX and the healthy population, apart from a few exceptions probably associated with concomitant DMARD therapy. $(19,33)$ In fact, according to the newest EULAR guidelines, treatment with IFX is safe up to the $20^{\text {th }}$ gestational week or longer, and there are no contraindications for IFX during breastfeeding. However, since there is a potential harmful effect on the neonatal immune response, vaccination with live vaccines is contraindicated during the first 6 months after birth. Three of the patients described here were on IFX just before or during pregnancy. The patient who was on regular therapy with IFX (along with MTX weekly, although it is questionable whether the patient had been taking MTX and in what dose, since she later stated she had been taking $5 \mathrm{mg}$ weekly instead of the prescribed 15 mg weekly) carried out the pregnancy without complications and gave birth to a healthy baby in the $36^{\text {th }}$ gestational week.

ADA is a recombinant completely human monoclonal antibody of the IgG1 subclass. It binds to the soluble TNF- $\alpha$ molecule, thus blocking its interaction with the receptors. Like other TNFis, it is a risk category $B$ medication according to the FDA. ADA crosses the placenta and consequently it can induce a risk of infections in newborns. The EMA recommended cessation of ADA treatment at least 5 months prior to conception, as well as withholding newborns from live vaccines for 5 months after the mother had the last treatment application. (10) According to the EULAR guidelines as well as the guidelines of the British Society for Rheumatology (BSR), pregnant patients can be treated with $\mathrm{ADA}$ up to the $20^{\text {th }}$ gestational week or longer, and it is safe during breastfeeding. $(19,34)$ One of our patients had been taking ADA until she was 4 weeks pregnant, and the pregnancy as well as fetal development continued without complications.

GOL is an IgG1-k human monoclonal antibody. It binds to soluble and transmembrane TNF- $\alpha$. According to the offical medication instructions, the EMA recommends discontinuation of GOL 6 months before će nije bilo neželjenih učinaka na tijek trudnoće, kao ni na zdravlje novorođenčeta.

IFX je kimeričko humano-mišje monoklonsko protutijelo IgG1 proizvedeno tehnologijom rekombinantnog DNK, a veže se jednakim afinitetom za topljivi i transmembranski oblik TNF- $\alpha$. Prema službenim uputama, ne savjetuje se uzimanje infliksimaba za vrijeme trudnoće i dojenja te se preporučuje prekid terapije minimalno 6 mjeseci prije začeća (9), no u literaturi se spominje i razdoblje od 2 mjeseca prije začeća, s obzirom na poluvijek lijeka u organizmu. U pogledu štetnih učinaka na ishode trudnoće nema statistički značajne razlike između bolesnica liječenih IFX-om i zdrave populacije, osim nekoliko iznimaka koje se mogu povezati i s istodobnom primjenom DMARD-a $(19,32)$. Dapače, prema najnovijim EULAR-ovim smjernicama, IFX se smije davati bolesnicama do 20 . tjedna trudnoće, pa i dulje, a siguran je i tijekom dojenja. Ipak, upozorava se na potencijalni štetni učinak na imunosni odgovor novorođenčeta te je cijepljenje živim cjepivima kontraindicirano u prvih 6 mjeseci djetetova života. Tri su prikazane bolesnice primale IFX neposredno prije ili za vrijeme trudnoće. Bolesnica koja je do trećeg tromjesečja primala redovito IFX uz MTX (uz napomenu da se postavlja pitanje je li bolesnica doista uzimala MTX i u kojoj dozi; prema njezinim navodima, doza MTX-a bila je $5 \mathrm{mg}$ na tjedan umjesto propisanih $15 \mathrm{mg}$ ) uredno je iznijela trudnoću te rodila zdravo dijete $\mathrm{u} 36$. tjednu.

Adalimumab je rekombinantno, potpuno humano monoklonsko protutijelo klase IgG1. Veže se s topljivim TNF- $\alpha$ i tako blokira njegovu interakciju s receptorima. Kao i ostali TNFi-ji, svrstan je u kategoriju rizika „B“ prema FDA. Adalimumab prolazi kroz posteljicu i tako može dovesti do povišenog rizika od infekcije u djeteta. Preporuka EMA-e jest da se prekine s primjenom ADA-e najmanje 5 mjeseci prije začeća te da se dojenčad ne cijepi živim cjepivima 5 mjeseci od posljednje primjene lijeka u majke (10). Prema najnovijim EULAR-ovim smjernicama i smjernicama Britanskoga reumatološkog društva (BSR), ADA se može davati bolesnicama do 20. tjedna trudnoće, pa i dulje, a siguran je i tijekom dojenja $(18,33)$. Jedna prikazana bolesnica liječena je primjenom ADA-e, a terapija je prekinuta u 4. tjednu trudnoće te su kasniji tijek trudnoće i razvoj ploda protekli bez komplikacija.

Golimumab je humano monoklonsko protutijelo IgG1 $\kappa$. Veže se s topljivim TNF- $\alpha$, kao i s TNF- $\alpha$ vezanim na membranu. U službenom opisu lijeka EMA preporučuje prekinuti primjenu GOL-a najmanje 6 mjeseci prije začeća, a zbog izlučivanja lijeka kroz posteljicu i u majčino mlijeko dojenčad se ne smije cijepiti živim cjepivima najmanje 6 mjeseci od posljednje primjene lijeka u majke (7). Do danas se nije pokazao štetan učinak GOL-a na razvoj ploda i tijek trudnoće, 
pregnancy. Because GOL crosses the placenta and is secreted into the mother's milk, newborns cannot be vaccinated with live vaccines at least 6 months after the last treatment application in the mother. (7) Adverse events in pregnancy and fetal development due to treatment with GOL have not been described so far. Nevertheless, because of the lack of information and experience, the EULAR advises avoiding GOL treatment in pregnancy. Despite some authors' suggestion that patients sholud not breastfeed within 6 months after the last treatment application, according to the EULAR guidelines GOL treatment is compatible with breastfeeding. $(19,34)$ Three of our patients had been taking GOL. Two of them stopped therapy according to the guidelines, 6 months prior to conceiving, and the third stopped therapy 2 months before pregnancy. None of these patients experienced complications during the pregnancy or further neonatal development.

TCZ is an IgG1 humanized monoclonal antibody targeted against the IL-6 receptor. Unlike TNFi, it is classified as a risk category $\mathrm{C}$ medication; there is not enough information to assess its safety in pregnancy and breastfeeding. The recommended minimum period from therapy cessation to conception is 3 months. Although research on the effect of TCZ in pregnancy is scarce, most of the papers do not report adverse events. $(35,36)$ Still, there is not enough data to reach definite conclusions, as there is the matter of an increased number of spontaneous abortions in animal models. (37) Given all of the reasons mentioned above, the EULAR advises withholding from TCZ just before or during pregnancy. Since there is also a lack of information on the concentration of secreted medication in breast milk, breastfeeding is not advised while on therapy. All three patients described here stopped taking TCZ at the time of conception. One patient delivered a healthy baby, another patient's course of pregnancy has been without complications so far. The third patient had a spontaneous abortion in the $7^{\text {th }}$ gestational week.

Along with biologic therapy, csDMARDs are almost always concomitant therapy. The effect of different csDMARDs on pregnancy and fetal development is well known and has been thorughly described. As stated in the EULAR and BSR guidelines issued in 2016, csDMARDs which are safe during pregnancy and lactation are SSZ, hydroxychloroqine and chloroqine, azathioprine, cyclosporine, and tacrolimus. Mycophenolate mofetil and tofacitinib should be discontinued 2 months before conception because they increase the risk of fetal malformations. The latter two DMARDs are also not compatible with breastfeeding. Cyclophosphamide (CYC) is teratogenic and, although it can be used exceptionally in the $2^{\text {nd }}$ and $3^{\text {rd }}$ trimesters, it is contraindicated in the first trimester of pregnancy. Breastfeeding is not advised while on therapy with no zbog manjka podataka i iskustva EULAR savjetuje izbjegavanje ove terapije tijekom trudnoće. Iako neki autori preporučuju da žene koje primaju GOL ne doje najmanje 6 mjeseci od posljednje primljene doze, prema najnovijim smjericama EULAR-a, terapija GOL-om kompatibilna je s dojenjem $(18,33)$. Tri prikazane bolesnice liječene su primjenom GOL-a. Dvije su bolesnice prekinule terapiju prema preporukama, 6 mjeseci prije začeća, dok ju je treća prekinula 2 mjeseca prije začeća. $U$ sve tri bolesnice nije bilo nikakvih komplikacija tijekom trudnoće i porođaja, kao ni u njihove novorođenčadi.

TCZ je humanizirano monoklonsko protutijelo potklase IgG1. Za razliku od TNFi-ja, svrstan je u kategoriju rizika "C" prema FDA. Nema dovoljno podataka za procjenu sigurnosti primjene lijeka u trudnoći i dojenju. Preporučeno minimalno razdoblje od prestanka uzimanja lijeka do začeća jest 3 mjeseca. Iako su istraživanja malobrojna, $u$ većini radova nije nađena učestala pojava nepoželjnih ishoda trudnoće $(34,35)$. Podataka ipak nema dovoljno za donošenje zaključaka pa ostaje otvoreno pitanje češćih spontanih pobačaja primijećenih na životinjskim modelima (36). Prema smjernicama EULAR-a, savjetuje se izbjegavati primjenu TCZ-a neposredno prije i tijekom trudnoće. Nedostaju podatci o koncentraciji izlučenog lijeka u majčinu mlijeku, zbog čega se savjetuje izbjegavati ovu terapiju za vrijeme dojenja (19). Sve tri bolesnice prikazane u ovom radu, koje su liječene TCZ-om, prekinule su terapiju nakon začeća. Jedna bolesnica rodila je zdravo dijete, u druge se bilježi uredno napredovanje trudnoće. Treća je bolesnica imala spontani pobačaj u 7. tjednu trudnoće.

Uz biološku terapiju bolesnice gotovo redovito uzimaju i terapiju nekim od konvencionalnih DMARD-a, s različitim učinkom na tijek i ishod trudnoće. Prema posljednjim preporukama EULAR-a i BSR-a iz 2016., konvencionalni DMARD-i koji se mogu davati u liječenju tijekom trudnoće i dojenja jesu SSZ, hidroksiklorokin i klorokin, azatioprin, ciklosporin i takrolimus. Prema smjernicama, mikofenolat-mofetil i tofacitinib moraju se prekinuti 2 mjeseca prije začeća, zbog povišenog rizika od malformacija, a nisu kompatibilni ni $s$ dojenjem. Ciklofosfamid je teratogen i kontraindiciran $\mathrm{u}$ 1. tromjesečju zbog povišenog rizika od razvoja malformacija ploda, no u iznimnim slučajevima može se davati u 2. i 3. tromjesečju. Svakako se ne savjetuje dojiti uz ovu terapiju $(18,33)$. Dvije su od prikazanih bolesnica tijekom trudnoće uzimale MTX i LEF, koji su kontraindicirani u trudnoći. MTX je antagonist folne kiseline koji interferira s produkcijom purina. Ima izrazita abortivna svojstva, a strukturne anomalije izazvane MTX-om povezane su s vremenom kada se daje i dozom (> $10 \mathrm{mg}$ na tjedan) (37). Zadržava se u organizmu od nekoliko tjedana do nekoliko mjeseci pa se 
CYC. $(19,34)$ Two of our patients were taking MTX and LEF during pregnancy, although both csDMARDs are contraindicated in pregnant patients. MTX is a folic-acid antagonist and it interferes with purine production. It is a potent abortifacient and MTX-induced structural anomalies are related to the time of administration and the dose given (>10mg/week). (38) Given that its washout period is long and lasts from a few weeks to several moths, women (and men) taking MTX should use contraception during the therapy and up to 6 months after discontinuation. (39) As reported by Spanish authors in 2009, the incidence of elective abortions was higher in women on MTX at the time of conception (18\%), and the number of miscarriages before the $20^{\text {th }}$ gestational week was also somewhat higher $(23 \%$ vs $15 \%)$ than in healthy controls. (40) So far, there are no official instructions on whether pregnancies started in patients on MTX should be artificially terminated or just closely monitored and MTX promptly discontinued. We described a case of a pregnant patient on MTX (and IFX) during the first two trimesters (at MTX $5 \mathrm{mg} /$ week), without any adverse effects in either the mother or the child.

LEF is contraindicated during pregnancy and lactation. The FDA has labeled it as a risk category $\mathrm{X}$ medication and therefore it should be either avoided as a treatment option in women of childbearing age, or taken along with contraception. The washout time for LEF is extremely long and can last up to 2 years. This period can be reduced with cholestiramine; a teratogenic effect is not expected when the plasma concentration of the active metabolite is below $0.02 \mathrm{mg} / \mathrm{L}$. A comparison of patients on cholestiramine who had been taking LEF just before or at the time of conception with the healthy population yielded no significant differences concerning fetal malformations. $(43,44)$ We reported the case of a patient with an unplanned pregnancy who was taking LEF and therefore had to undergo a medically induced abortion.

\section{CONCLUSION}

Our results are concordant with the reports published in the medical literature to date. During pregnancy or at the time of conception, 15 of our patients had been taking one of the TNFis and 1 patient was on the IL-6 blocker; the minimum advised period without therapy before conception was not achieved. Only two patients, both receiving GOL, complied with the offical recommendation and discontinued biologic therapy 6 months prior to pregnancy. Both of them had normal pregnancies and delivered healthy babies. Of the mentioned 16 patients, three had medically advised artifical abortions; in two cases because the patients were on $\mathrm{X}$-labeled csDMARDs (MTX and LEF) and the probability of a teratogenic effect was high. The third pa- ženama (i muškarcima) na terapiji MTX-om preporučuje kontracepcija tijekom uzimanja MTX-a do 6 mjeseci nakon prestanka terapije (38). U radu španjolskih autora, objavljenom 2009. g., incidencija elektivnih pobačaja u žena koje su uzimale MTX tijekom začeća bila je veća (18\%) nego u općoj populaciji, kao i broj spontanih pobačaja prije 20 . tjedna (u $23 \%$ naspram $15 \%$ ) (39). Zasad nema točnih smjernica o tome treba li se trudnoća započeta uz MTX arteficijalno završiti ili valja samo promptno ukinuti terapiju, a trudnoću pozorno pratiti. Opisali smo bolesnicu koja je uzimala MTX (uz IFX) u dozi od navodno $5 \mathrm{mg}$ na tjedan tijekom prva dva tromjesečja trudnoće, bez neželjenih učinaka na trudnoću i dijete.

Primjena LEF-a kontraindicirana je u trudnoći i dojenju. Prema FDA, riječ je o kategoriji „X“, stoga žene u reproduktivnoj dobi ne smiju uzimati LEF bez istodobne uporabe pouzdane kontracepcije. LEF se iznimno dugo zadržava u organizmu; vrijeme „ispiranja“ lijeka može trajati i do 2 godine. Ovo se razdoblje može skratiti primjenom kolestiramina. Teratogeni se učinak ne očekuje pri koncentraciji aktivnog metabolita u plazmi nižoj od $0,02 \mathrm{mg} / \mathrm{L}(40,41)$. U trudnica izloženih LEF-u neposredno prije trudnoće i za vrijeme začeća nisu nađene znatnije razlike u razvoju fetalnih malformacija u usporedbi sa zdravom populacijom ako je učinjeno ispiranje lijeka kolestiraminom (42, 43). U radu prikazana bolesnica neplanirano je zanijela za vrijeme uzimanja LEF-a pa je zbog toga trudnoća arteficijalno prekinuta.

\section{ZAKLJUČAK}

Prikazani se rezultati ne razlikuju od rezultata objavljenih u dostupnoj medicinskoj literaturi. Od prikazanih bolesnica njih 15 primalo je jedan od lijekova koji pripadaju skupini TNFi-ja i jedna je bolesnica uzimala blokator IL-6 tijekom trudnoće ili neposredno prije začeća, tj. minimalno razdoblje od prestanka primjene lijeka do samog začeća nije ostvareno. Dvije su bolesnice, obje liječene GOL-om, poštovale navedeno minimalno razdoblje te je od posljednje primjene lijeka do začeća prošlo 6 mjeseci. Obje su rodile zdravo dijete. Od opisanih 16 bolesnica tri su imale medicinski indiciran prekid trudnoće. Dvije od njih uzimale su csDMARD-e (MTX i LEF), koji su zbog svojih teratogenih karakteristika svrstani u kategoriju rizika „X“. Treća je bolesnica uzimala IFX i prekinula je terapiju u vrijeme začeća, no medicinski je indiciran prekid trudnoće zbog teških malformacija ploda, koje se ipak ne mogu sa sigurnošću povezati s IFX-om za koji se navodi da je siguran u primjeni tijekom trudnoće.

$S$ obzirom na veliku prevalenciju upalnih reumatskih bolesti u bolesnica generativne dobi, potrebno je pažljivo planirati diferentnu terapiju da bi se izbjegli štetni učinci na reproduktivno zdravlje. Nadalje, važno 
tient was on IFX and discontinued it at the time of conception. Unfortunately, the pregnancy had to be terminated because of severe fetal malformations. Still, it is not possible to associate the occurrence of fetal malformations with IFX with certainty, since it has been reported as relatively safe during pregnancy.

Given that the prevalence of inflammatory rheumatic disease is high in patients of childbearing age, careful therapy planning is of utmost importance in order to avoid adverse effects and impairment of reproductive health. Furthermore, it is also necessary to consider the treatment of male patients, as it affects family planning as well. The emphasis is on proper timing; rheumatic disase should be well under control and in a stable remission for a period of at least 3-6 months before pregnancy is attempted. Neither the FDA nor the EMA have declared biologic therapy safe during pregnancy and lactation. Nevertheless, expert rheumatologists, gynecologists, and neonatologists agree on the acceptable safety of some biologc agents in pregnant patients. For the time being, there is no evidence that biologic therapy should be discontinued after conception. Depending on the biologic agent they are taking, patients are advised to stop therapy in the $32^{\text {nd }}$ gestational week at the latest, mostly for the sake of the infant's safety and prevention of early neonatal infections. A multidisciplinary approach including rheumatologists, obstetric gynecologists, and neonatologists along with mother counseling is essential in a careful pregnancy monitoring.

\section{Acknowledgement}

We thank all the expert rheumatologists form the Division of Clinical Immunology and Rheumatology, Department of Internal Medicine, UHC Zagreb, who took part in the treatment of the patients described in this article.

\section{Abbreviations}

ADA - Adalimumab

AS - Ankylosing spondylitis

BASDAI - Bath Ankylosing Spondylitis Disease Activity Index

BSR - British Society for Rheumatology

CZP - Certolizumab-pegol

DAS 28-SE - Disease Activity Score 28 (calculated using erythrocyte sedimentation rate)

DMARD - Disease-modifying antirheumatic drug

EMA - European Medicines Agency

ETA - Etanercept

EULAR - European League Against Rheumatism

$\mathrm{Fab}$ - Antigen-binding fragment

Fc(-regija) - Fragment crystallizable region

FcRn - Neonatal Fc receptor je voditi računa i o muškarcima koji boluju od upalnih reumatskih bolesti te o utjecaju njihova liječenja na planiranje obitelji. Svakako se naglašava planiranje trudnoće $\mathrm{u}$ mirnoj fazi reumatske bolesti, tj. nakon najmanje 3 - 6 mjeseci stabilne remisije. FDA i EMA nisu proglasile nijedan biološki lijek sigurnim u vrijeme trudnoće i laktacije. Ipak, stručnjaci reumatolozi, ginekolozi i neonatolozi došli su do konsenzusa da se neki od lijekova mogu s relativno velikom sigurnošću uzimati i tijekom trudnoće. Zasad nema dokaza o opravdanom prekidu trudnoće u bolesnica koje su zanijele za vrijeme biološke terapije. Trudnicama se savjetuje prekid biološke terapije, ovisno o lijeku koji uzimaju, najkasnije do 32. tjedna trudnoće, ponajviše zbog sigurnosti novorođenčeta i sprječavanja infekcija u ranoj dojenačkoj dobi. Naglašena je potreba multidisciplinarnog pristupa u pomnom nadzoru trudnoće u koji moraju biti uključeni reumatolog, ginekolog-opstetričar i pedijatar-neonatolog, uz savjetovanje $s$ majkom.

\section{Zahvala}

Zahvaljujemo svim liječnicima specijalistima Zavoda za kliničku imunologiju i reumatologiju Klinike za unutarnje bolesti KBC-a Zagreb koji su sudjelovali u liječenju bolesnica prikazanih u ovom članku.

\section{Popis kratica}

ADA - Adalimumab

AS - Ankilozantni spondilitis

BASDAI - Indeks aktivnosti bolesti za ankilozantni spondilitis

BSR - Britansko reumatološko društvo

CZP - Certolizumab-pegol

DAS 28-SE - Indeks aktivnosti bolesti 28 (izračunat prema vrijednosti sedimentacije eritrocita

DMARD - Antireumatici koji mijenjaju tijek bolesti

EMA - Europska medicinska agencija

ETA - Etanercept

EULAR - Europska liga protiv reumatizma

Fab - Dio koji veže antigen

$\mathrm{Fc}(-$ regija) - Područje kristalizirajućeg dijela

FcRn - Neonatalni Fc receptor

FDA - Agencija za hranu i lijekove

GK - Glukokortikoid

GOL - Golimumab (Simponi)

HLA-B27 - humani leukocitni antigen B27

IFX - Infliksimab

IgG1 - Imunoglobulin G1

IgM - Imunoglobulin M

LEF - Leflunomid

MTX - Metotreksat

NSAID - Nesteroidni antireumatik

PsA - Psorijatični artritis 
FDA - Food and Drug Administration /

GK - Glucocorticoid

GOL - Golimumab (Simponi)

HLA-B27 - Human leukocyte antigen B27

IFX - Infliximab

IgG1 - Immunoglobulin G1

IgM - Immunoglobulin M

LEF - Leflunomide

MTX - Methotrexate

NSAID - Non-steroidal anti-inflammatory drug

PsA - Psoriatic arthritis

RA - Rheumatoid arthritis

SE - Erythrocyte sedimentation rate

SnSA - Seronegative spondyloarthropathy

SSZ - Sulphasalazine

TCZ - Tocilizumab

TNF- $\alpha$ - Tumor necrosis factor- $\alpha$

TNFi - Tumor necrosis factor- $\alpha$ inhibitor

TNFR2 - Tumor necrosis factor receptor 2

VACTERL - Vertebral defects, Anal atresia, Cardiac defects, Tracheo-esophageal fistula, Renal anomalies, Limb abnormalities

Conflict of interest statement: Authors declare no conflict of interest.

\section{REFERENCES / LITERATURA}

1. Verstappen SM, King Y, Watson KD, Symmons DPM, Hyrich KL. Anti-TNF therapies and pregnancy: outcome of 130 pregnancies in the British Society for Rheumatology Biologics Register. Ann Rheum Dis. 2011;70(5):823-6.

2. Bogas M, Leandro MJ. Biologic Therapy and Pregnancy. A Systematic Literature Review. Acta Reumatol Port. 2011;36(3): 219-32.

3. Diav-Citrin O, Otcheretianski-Volodarsky A, Shechtman S, Ornoy A. Pregnancy outcome following gestational exposure to TNF-alpha-inhibitors: a prospective, comparative, observational study. Reprod Toxicol. 2014;43:78-84.

4. Calligaro A, Hoxha A, Ruffatti A, Punzi L. Are biological drugs safe in pregnancy? Reumatismo. 2015;66(4):304-17.

5. Østensen M. The use of biologics in pregnant patients with rheumatic disease. Expert Rev Clin Pharmacol. 2017;10(6): 661-9.

6. US Food and Drug Administration. United States FDA pharmaceutical pregnancy categories. Dostupno na: http://depts. washington.edu/druginfo/Formulary/Pregnancy.pdf. Pristupljeno: 21. 8. 2014.

7. EMA. Simponi, INN-golimumab. Product information. Dostupno na: http://www.ema.europa.eu/docs/en_GB/document _library/EPAR_-_Product_Information/human/000992/WC 500052368.pdf. Pristupljeno: 3. 4. 2018.

8. EMA. Enbrel, INN-etanercept. Product information. Dostupno na: http://www.ema.europa.eu/docs/en_GB/document_library/
RA - Reumatoidni artritis

SE - Sedimentacija eritrocita

SnSA - Seronegativna spondiloartropatija

SSZ - Sulfasalazin

TCZ - Tocilizumab

TNF- $\alpha$ - Čimbenik nekroze tumora- $\alpha$

TNFi - Inhibitor čimbenika nekroze tumora- $\alpha$

TNFR2 - Receptor 2 čimbenika nekroze tumora

VACTERL - Defekti kralježnice, atrezija anusa, srčana oštećenja, traheoezofagealna fistula, anomalije bubrega, defomiteti udova

IZjaVA o sukobu interesa: Autori izjavljuju da nisu u sukobu interesa.

EPAR_-_Product_Information/human/000262/WC500027361. pdf. Pristupljeno: 3. 4. 2018.

9. EMA. Remicade, INN-infliximab. Product information. Dostupno na: http://www.ema.europa.eu/docs/en_GB/document_ library/EPAR___Product_Information/human/000240/WC500 050888.pdf. Pristupljeno: 3. 4. 2018.

10. EMA. Humira, INN-adalimumab. Product information. Dostupno na: http://www.ema.europa.eu/docs/en_GB/document_ library/EPAR_-_Product_Information/human/000481/WC500 050870.pdf. Pristupljeno: 3. 4. 2018.

11. EMA. RoActemra, INN-tocilizumab. Product information. Dostupno na: http://www.ema.europa.eu/docs/en_GB/document library/EPAR_-_Product_Information/human/000955/WC500 054890.pdf. Pristupljeno: 3. 4. 2018.

12. Hyrich KL, Verstappen SM. Biologic therapies and pregnancy: the story so far. Rheumatology. 2014;53(8):1377-85.

13. Anić B, Čikeš N. Primjena lijekova u trudnica s upalnim reumatskim bolestima. Reumatizam. 2006;53:55-8.

14. Sentić M, Barešić M, Anić B i sur. Trudnoća u bolesnica koje primaju biološki lijek zbog upalne reumatske bolesti. Liječ Vjesn. 2010;132:317-8.

15. Bakula M, Cerovec M, Anić B, Čikeš N. Trudnoća u bolesnice $s$ reumatoidnim artritisom koja je liječena metotreksatom i infliksimabom. Reumatizam. 2016;63(1):6-9.

16. Levy RA, de Jesús GR, de Jesús NR, Klumb EM. Critical review of the current recommendations for the treatment of systemic 
inflammatory rheumatic diseases during pregnancy and lactation. Autoimmun Rev. 2016;15(10):955-63.

17. Pottinger E, Woolfy RT, Exton LS, Burden AD, Nelson-Piercy $\mathrm{C}$, Smith $\mathrm{CH}$. Exposure to biological therapies during conception and pregnancy: a systematic review. Br J Dermatol. 2018; 178(1):95-102.

18. Götestam Skorpen C, Hoeltzenbein M, Tincani A i sur. The EULAR points to consider for use of antirheumatic drugs before pregnancy, and during pregnancy and lactation. Ann Rheum Dis. 2016;75(5):795-810.

19. Carter JD, Valeriano J, Vasey FB. Tumor necrosis factor inhibition and VATER association: a causal relationship? J Rheumatol. 2006;33:1014-7.

20. Koren G, Inoue M. Do tumor necrosis factor inhibitors cause malformations in humans? J Rheumatol. 2009;36(3):465-6.

21. Carter JD, Ladhani A, Ricca LR, Valeriano J, Vasey FB. A safety assessment of tumor necrosis factor antagonists during pregnancy: a review of the Food and Drug Administration database. J Rheumatol. 2009;36(3):635-41.

22. Chambers CD, Johnson DL. Emerging data on the use of antitumor necrosis factor-alpha medications in pregnancy. Birth Defects Res A Clin Mol Teratol. 2012;94:607-11.

23. Porter ML, Lockwood SJ, Kimball AB. Update on biologic safety for patients with psoriasis during pregnancy. Int J Wom Dermatol. 2017;3(1):21-5.

24. Pasut G. Pegylation of biological molecules and potential benefits: Pharmacological properties of certolizumab pegol. BioDrugs. 2014;28(1):15-23.

25. Porter C, Armstrong-Fisher S, Kopotsha T i sur. Certolizumab pegol does not bind the neonatal Fc receptor (FcRn): consequences for FcRn-mediated in vitro transcytosis and ex vivo human placental transfer. J Reprod Immunol. 2016;116:7-12.

26. Clowse ME, Wolf DC, Förger F i sur. Pregnancy outcomes in subjects exposed to certolizumab pegol. J Rheumatol. 2015; 42(12):2270-8.

27. Marin J, Acosta Felquer ML, Soriano ER. Spotlight on certolizumab pegol in the treatment of axial spondyloarthritis: efficacy, safety and place in therapy. Open Access Rheumatol. 2018;10:33-41.

28. Mahadevan U, Wolf DC, Dubinsky M i sur. Placental transfer of antitumor necrosis factor agents in pregnant patients with inflammatory bowel disease. Clin Gastroenterol Hepatol. 2013; 11(3):286-92.

29. Mariette X, Förger F, Abraham B i sur. Lack of placental transfer of certolizumab pegol during pregnancy: results from CRIB, a prospective, postmarketing, pharmacokinetic study. Ann Rheum Dis. 2018;77(2):228-33.
30. Lim H, Lee SH, Lee HT i sur. Structural Biology of the TNFa Antagonists Used in the Treatment of Rheumatoid Arthritis. Int J Mol Sci. 2018;19(3). pii: E768.

31. Johnson DL, Jones KL, Chambers CD. Pregnancy outcome in women exposed to etanercept: the OTIS autoimmune diseases in pregnancy project. Dostupno na: www.otispregnancy.org/ readResource.php? $r=108642$.

32. Krause ML, Amin S, Makol A. Use of DMARDs and biologics during pregnancy and lactation in rheumatoid arthritis: what the rheumatologist needs to know. Ther Adv Musculoskel Dis. 2014;6(5):169-84.

33. Flint J, Panchal S, Hurrell A. BSR and BHPR guideline on prescribing drugs in pregnancy and breastfeeding-Part I: standard and biologic disease modifying anti-rheumatic drugs and corticosteroids. Rheumatology (Oxford). 2016;55(9):1693-7.

34. Weber-Schoendorfer C, Schaefer C. Pregnancy outcome after tocilizumab therapy in early pregnancy-a case series from the German Embryotox Pharmacovigilance Center. Reprod Toxicol. 2016;60:29-32.

35. Nakajima K, Watanabe O, Mochizuki M i sur. Pregnancy outcomes after exposure to tocilizumab: A retrospective analysis of 61 patients in Japan. Mod Rheumatol. 2016;26(5):667-71.

36. Hoeltzenbein M, Beck E, Rajwanshi R i sur. Tocilizumab use in pregnancy: Analysis of a global safety database including data from clinical trials and post-marketing data. Semin Arthritis Rheum. 2016;46(2):238-45.

37. Methotrexate $2.5 \mathrm{mg}$ tablets. Dostupno na: https://www.medicines.org.uk/emc/product/511/smpc. Pristupljeno: 3. 4. 2018.

38. Martínez Lopez JA, Loza E, Carmona L. Systematic review on the safety of methotrexate in rheumatoid arthritis regarding the reproductive system (fertility, pregnancy, and breastfeeding). Clin Exp Rheumatol. 2009;27:678-84.

39. Agencija za lijekove i medicinske proizvode. Leflunomid; Arava. Uputa o lijeku. Dostupno na: http://www.almp.hr/upl/lijekovi/ PIL/UP-I-530-09-06-02-174.pdf. Pristupljeno: 3. 4. 2018.

40. Arava $20 \mathrm{mg}$ tablets. Dostupno na: http://www.medicines.org. uk/emc/medicine/26344. Pristupljeno: 3. 4. 2018.

41. Cassina M, Johnsson DL, Robinson LK i sur. Pregnancy Outcome in Women Exposed to Leflunomide Before or During Pregnancy. Arthritis Rheum. 2012;64(7):2085-94.

42. Hajdyla-Banaś I, Banas T, Rydz-Stryszowska I i sur. Pregnancy course and neonatal outcome after exposure to leflunomide - 2 case reports and review of literature. Przegl Lek. 2009;66 (12):1069-71.

43. Bermas BL. Non-steroidal anti inflammatory drugs, glucocorticoids and disease modifying anti-rheumatic drugs for the management of rheumatoid arthritis before and during pregnancy. Curr Opin Rheumatol. 2014;26(3):334-40. 